\title{
Effect of NIK-247 on Basal Concentrations of Extracellular Acetylcholine in the Cerebral Cortex of Conscious, Freely Moving Rats
}

\author{
Yutaka Ishii ${ }^{1}$, Jun Kojima ${ }^{1}$, Naoko Ikeda ${ }^{1}$ and Koichiro Kawashima ${ }^{2}$ \\ 'Division of Pharmacology, Omiya Research Laboratory, Nikken Chemicals Co., Ltd., 346, 1 Chome, Kitabukuro, Omiya, Saitama 330, Japan \\ ${ }^{2}$ Department of Pharmacology, Kyoritsu College of Pharmacy, I-5-30 Shibakoen, Minato-ku, Tokyo 105, Japan
}

Received May 9, 1994 Accepted July 22, 1994

\begin{abstract}
We studied the effect of orally administered NIK-247 (9-amino-2,3,5,6,7,8-hexahydro- $1 \mathrm{H}$ cyclopenta $[b]$ quinoline monohydrochloride monohydrate) on basal extracellular acetylcholine (ACh) concentrations in the rat cerebral cortex using microdialysis without the addition of cholinesterase inhibitor to the perfusion fluid and radioimmunoassay for ACh. In addition, the effect of oral administration of NIK247 on acetylcholinesterase (AChE) activity in rat cerebral cortex was determined. The mean basal ACh content in the perfusate from the cerebral cortex of freely moving rats was $123.2 \pm 21.8 \mathrm{fmol} / 30 \mathrm{~min}(\mathrm{n}=7)$. NIK-247 (2.5-10.0 mg/kg, p.o.) increased the ACh content of the perfusate in a dose-dependent manner. NIK-247 at $10 \mathrm{mg} / \mathrm{kg}$ significantly increased the ACh content in the perfusate from 0.5 to $2.5 \mathrm{hr}$ after administration, and the maximum increase was attained at $1 \mathrm{hr}$ after administration. 9-Amino-1,2,3,4tetrahydroacridine $(5 \mathrm{mg} / \mathrm{kg}, \mathrm{p} . \mathrm{o}$.) and physostigmine $(0.5 \mathrm{mg} / \mathrm{kg}$, i.p.) significantly increased the ACh content in the perfusate from 1 to $2 \mathrm{hr}$ and from 0.5 to $1.5 \mathrm{hr}$ after administration, respectively. AChE activities in the cerebral cortex were about $32 \%$ and $12 \%$ below the control value at $1 \mathrm{hr}$ and $3 \mathrm{hr}$ after administration of NIK-247 at $10 \mathrm{mg} / \mathrm{kg}$, respectively. These findings demonstrate that NIK-247 increases extracellular ACh concentration and inhibits $\mathrm{AChE}$ activity in the cerebral cortex after oral administration, and they suggest that NIK-247 facilitates central cholinergic transmission.
\end{abstract}

Keywords: NIK-247, Acetylcholine concentration (basal extracellular), Cerebral cortex microdialysis (rat), Acetylcholinesterase activity, Radioimmunoassay

Deficits in the central cholinergic system, such as decreased acetylcholine (ACh) content and choline acetyltransferase (CAT) activity in the nucleus basalis of Meynert, have been reported in patients with clinically diagnosed Alzheimer's disease (1-4). NIK-247 (9-amino2,3,5,6,7,8-hexahydro- $1 H$-cyclopenta[b]quinoline monohydrochloride monohydrate) has been reported to inhibit acetylcholinesterase (AChE) (5) and to improve learning and memory performance in animal studies $(6-10)$. Oral administration of NIK-247 increases ACh content in the brain and increases ACh efflux from brain slices $(5,11)$. These findings indicate that NIK-247 increases ACh concentration in the cholinergic synaptic cleft via inhibition of $\mathrm{AChE}$ and activates central cholinergic transmission. For precise determination of the effect of NIK-247 on central cholinergic function, changes in extracellular $\mathrm{ACh}$ concentrations at cholinergic nerve endings must be measured under basal conditions without the use of cholinesterase $(\mathrm{ChE})$ inhibitor in the perfusion fluid.
The intracerebral microdialysis procedure permits estimation of cholinergic neuronal activity in discrete regions of the brain by measurement of $\mathrm{ACh}$ content in the perfusate. Since $\mathrm{ACh}$ released from nerve endings is hydrolyzed rapidly by $\mathrm{AChE}$, extracellular concentrations of $\mathrm{ACh}$ under physiological conditions are very low. Due to difficulties associated with measurement of small amounts of ACh using conventional methods, most microdialysis studies have required the addition of physostigmine (PHY), a ChE inhibitor, to the perfusion fluid to increase the recovery of $\mathrm{ACh}$ in the perfusate. However, perfusion of $\mathrm{ChE}$ inhibitor induces artificial activation of cholinergic neurons and thus makes interpretation of the effects of drugs difficult (12-14).

Recently, effects of some drugs on extracellular $\mathrm{ACh}$ concentrations have been reported using the microdialysis procedure without the use of ChE inhibitor in the perfusion fluid $(12-17)$. However, in those studies, the effects of only i.p. injection of drugs were examined (15-17). In 
the present study, we investigated the effects of orally administered NIK-247 on the extracellular ACh concentration in the cerebral cortex of conscious, freely moving rats using a microdialysis procedure without addition of $\mathrm{ChE}$ inhibitor to the perfusion fluid and radioimmunoassay (RIA) for ACh (12). The effects of NIK-247 were compared with those of 9-amino-1,2,3,4-tetrahydroacridine (THA) and PHY. We also studied the effects of oral administration of NIK-247 on AChE activity in rat cerebral cortex.

\section{MATERIALS AND METHODS}

\section{Animals}

Male Wistar rats (Nihon SLC, Shizuoka; 9 weeks of age) were housed at a temperature of $23 \pm 3{ }^{\circ} \mathrm{C}$, humidity of $50 \pm 15 \%$ and a $12 \mathrm{hr}$ light $/ 12 \mathrm{hr}$ dark cycle (lights on 8:00, off 20:00) for at least 1 week before the experiment.

\section{Drugs}

NIK-247 was supplied from Nikken Chemicals Co., Ltd. (Omiya), THA hydrochloride monohydrate and PHY salicylate from Sigma (St. Louis, MO, USA), $\left[{ }^{3} \mathrm{H}\right]-$ ACh chloride $(2.85 \mathrm{TBq} / \mathrm{mmol})$ from Amersham (Buckinghamshire, UK) and bovine $\gamma$-globulin from Miles (Kankakee, IL, USA). All other chemicals were of reagent grade and obtained from commercial sources.

NIK-247 and THA were dissolved in distilled water and administered by gavage. PHY was dissolved in $0.9 \%$ physiological saline and injected i.p.

\section{Surgery}

Rats were anesthetized with pentobarbital-Na ( 50 $\mathrm{mg} / \mathrm{kg}$, i.p.) and positioned in a stereotaxic apparatus (SM-15S; Narishige, Tokyo). The skull was exposed and a hole drilled for implantation of a microdialysis probe. The microdialysis probe $(3.0-\mathrm{mm}$ membrane and $0.5-\mathrm{mm}$ diameter; CMA/12; Carnegie Medicin, Stockholm, Sweden) was implanted into the left cerebral cortex at $40^{\circ}$ from the vertical axis, to a depth of $3.5 \mathrm{~mm}$ from the cortical surface and at $2.0 \mathrm{~mm}$ anterior and $2.0 \mathrm{~mm}$ lateral to the bregma, according to the rat brain stereotaxic coordinates indicated in the atlas of Paxinos and Watson (18), and permanently secured by dental cement to bone screws. Following surgery, rats were housed individually in home cages. Placement of the probe within the cerebral cortex was confirmed by visual inspection of the probe track at the end of the experiment.

\section{Microdialysis}

Three days after implantation, the microdialysis probe was connected to a 2-channel swivel (Eicom, Kyoto) and Ringer's solution $(147 \mathrm{mM} \mathrm{NaCl}, 4.0 \mathrm{mM} \mathrm{KCl}$ and 2.3
$\mathrm{mM} \mathrm{CaCl}_{2}$ ) was perfused by using a microperfusion pump (Model 22; Harvard, South Natick, MA, USA) at the rate of $2 \mu \mathrm{l} / \mathrm{min}$. The perfusate was discarded during the first hour of perfusion and then collected at 30-min intervals into tubes containing $35 \mu 1$ of $0.01 \mathrm{~N}$ acetic acid in an ice-water bath.

After three fractions had been collected, rats were administered distilled water $(5 \mathrm{ml} / \mathrm{kg}, \mathrm{p} .0$.$) , saline (2$ $\mathrm{ml} / \mathrm{kg}$, i.p.), NIK-247 (2.5, 5.0 or $10.0 \mathrm{mg} / \mathrm{kg}$, p.o.), THA (5.0 mg/kg, p.o.) or PHY (0.5 mg/kg, i.p.).

\section{Determination of ACh by RIA}

The amount of $\mathrm{ACh}$ in the perfusate was measured by RIA using the method of Kawashima et al. (12). RIA was performed with rabbit antiserum raised against choline hemiglutarate-bovine serum albumin conjugates and $\left[{ }^{3} \mathrm{H}\right]$ ACh with a specific activity of $2.85 \mathrm{TBq} / \mathrm{mmol}$ (Amersham). This assay is specific for $\mathrm{ACh}$, and its levels of cross-reactivity with choline, phosphatidylcholine and phosphorylcholine are each less than $0.012 \%$. The sensitivity of the assay was $3 \mathrm{pg} /$ tube (about $20 \mathrm{fmol} /$ tube). For the RIA buffer, $0.15 \mathrm{M}$ Tris-HCl, pH 7.4, was used. A $100-\mu$ l portion of $\left[{ }^{3} \mathrm{H}\right] \mathrm{ACh}$ chloride (about $9,000 \mathrm{dpm}$ ) in $0.15 \mathrm{M}$ Tris- $\mathrm{HCl}$ buffer was added to a tube containing a mixture of $100 \mu$ of diluted antiserum $(1: 1,000)$ in $0.4 \%$

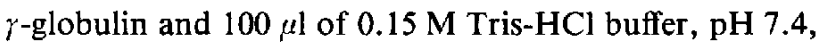
and the perfusate was collected for $30 \mathrm{~min}$. The contents of the tube were incubated overnight at $4^{\circ} \mathrm{C}$. The antibody-bound $\left[{ }^{3} \mathrm{H}\right] \mathrm{ACh}$ was separated by an ammonium sulfate method, and the radioactivity of the antibodybound fraction was then determined by a liquid scintillation counter (LSC3000; Aloka, Tokyo). The same volume of perfusion fluid served as a blank.

The amount of $\mathrm{ACh}$ in the perfusate was calculated by subtracting the blank value from that for the sample. Contents of ACh in the perfusate are shown as $\mathrm{fmol} / 30 \mathrm{~min}$ (means \pm S.E.).

\section{AChE activity}

Animals were sacrificed by decapitation at $0.5,1,3$ or $6 \mathrm{hr}$ after the oral administration of NIK-247 at doses of 3 or $10 \mathrm{mg} / \mathrm{kg}$. The cerebral cortex was rapidly dissected out. AChE activity was determined using the method of Zusho (19). Briefly, the cortex was homogenized in 10 volumes of $50 \mathrm{mM}$ phosphate buffer $(\mathrm{pH} \mathrm{7.4)}$. The $\mathrm{pH}$ of a $4 \mathrm{ml}$ portion of the homogenate in a reaction cell was monitored using a pH-electrode during continuous stirring at $37^{\circ} \mathrm{C}$. After the $\mathrm{pH}$ had stabilized, a $20-\mu l$ portion of $600 \mathrm{mM} \mathrm{ACh}$ in $50 \mathrm{mM}$ phosphate buffer was added to the cell. Changes in $\mathrm{pH}$ due to hydrolysis of $\mathrm{ACh}$ were recorded continuously. AChE activity was calculated from the time required to reach the end of the hydrolysis reaction and expressed as $\mu \mathrm{mol} / \mathrm{g}$ wet tissue $/ \mathrm{min}$. 


\section{Statistical analyses}

Two-way analysis of variance followed by Dunnett's multiple comparison test or Student's $t$-test was used for comparison of findings of the control and drug-treated groups. $P$ values $<0.05$ were considered to indicate statistical significance.

\section{RESULTS}

\section{Effects of NIK-247, THA and PHY on extracellular ACh} concentrations

Using RIA, it was possible to determine the amount of $\mathrm{ACh}$ in the perfusate from the cerebral cortex of conscious, freely moving rats for at least $6.5 \mathrm{hr}$ without the addition of ChE inhibitor to the perfusion fluid (Figs. 1-3). Basal ACh content in the perfusate prior to administration of vehicle was $123.2 \pm 21.8 \mathrm{fmol} / 30 \mathrm{~min}$ $(\mathrm{n}=7)$, and it was stable throughout the experiment. Basal ACh content in the perfusate was not influenced by the handling required for administration of distilled water (p.o.) or physiological saline (i.p.) (Figs. 1-3).

Oral administration of NIK-247 increased the ACh content of the perfusate in a dose-dependent manner (Fig. 1). The increase by NIK-247 at doses of 5 and $10 \mathrm{mg} / \mathrm{kg}$ was statistically significant compared with the control. The maximum increases, observed at $1 \mathrm{hr}$ after the administration of NIK-247 at 5 and $10 \mathrm{mg} / \mathrm{kg}$, were 2.5 and 4.7 times the control level, respectively. NIK-247 at $10 \mathrm{mg} / \mathrm{kg}$ significantly increased $\mathrm{ACh}$ content between $0.5-2.5 \mathrm{hr}$ after administration; however, ACh content in the perfusate returned to the control levels within $3.5 \mathrm{hr}$ of adminis-

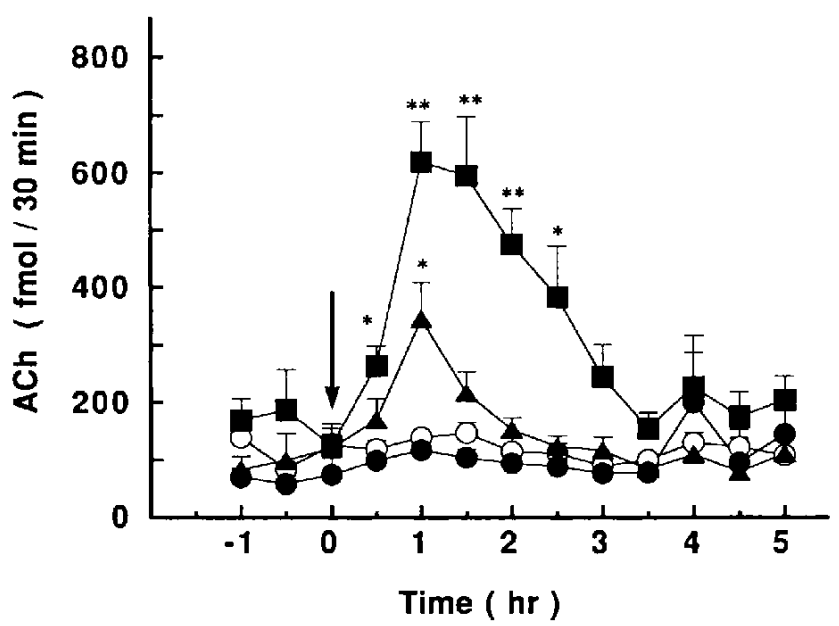

Fig. 1. Effect of NIK-247 on the ACh content in the perfusate from the cerebral cortex of conscious, freely moving rats. Vehicle (D.W., $5 \mathrm{ml} / \mathrm{kg}$ ) or NIK-247 was administered orally (indicated by arrow). $\bigcirc$, control (vehicle) $(\mathrm{n}=7) ; 0,2.5 \mathrm{mg} / \mathrm{kg}(\mathrm{n}=6) ; \Delta, 5.0 \mathrm{mg} / \mathrm{kg}$ $(\mathrm{n}=7) ; \square, 10.0 \mathrm{mg} / \mathrm{kg}(\mathrm{n}=6)$. Values are means \pm S.E. ${ }^{*} \mathrm{P}<0.05$, ${ }^{* *} \mathbf{P}<0.01$ vs control.

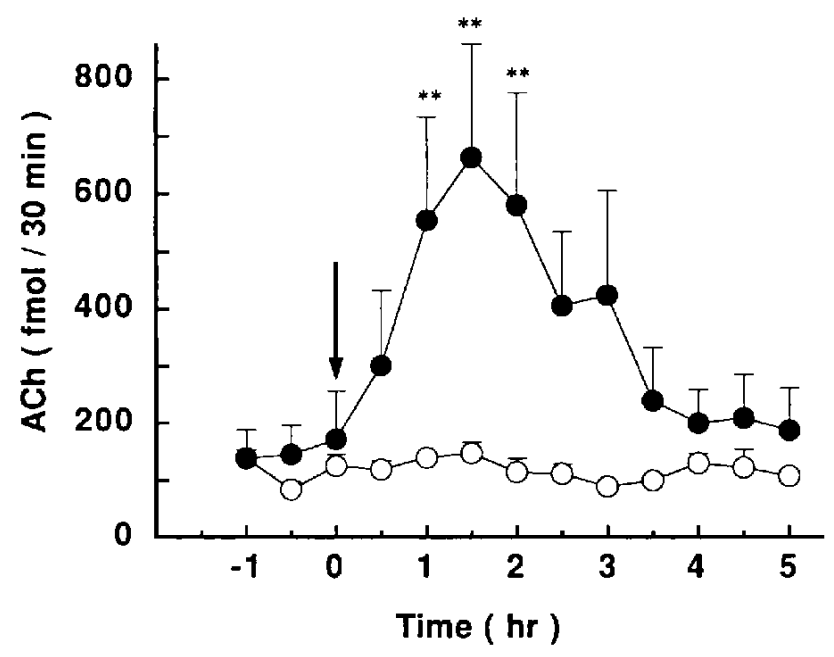

Fig. 2. Effect of THA on the ACh content in the perfusate from the cerebral cortex of conscious, freely moving rats. Vehicle (D.W., $5 \mathrm{ml} / \mathrm{kg}$ ) or THA was administered orally (indicated by arrow). $O$, control (vehicle) $(n=7) ; O, 5.0 \mathrm{mg} / \mathrm{kg}(n=7)$. Values are means \pm S.E. ${ }^{* *} \mathrm{P}<0.01$ vs control.

tration.

THA ( $5 \mathrm{mg} / \mathrm{kg}$, p.o.) significantly increased ACh content in the perfusate from 1 to $2 \mathrm{hr}$ after administration, and the peak effect (4.5 times control level) was noted at $1.5 \mathrm{hr}$ after administration (Fig. 2). The ACh content in the perfusate returned to the control levels by $3.5 \mathrm{hr}$ after administration.

PHY $(0.5 \mathrm{mg} / \mathrm{kg}$, i.p.) significantly increased the ACh content in the perfusate from 0.5 to $1.5 \mathrm{hr}$ after administration. The maximal increase (4.9 times the control level) was observed at $1 \mathrm{hr}$ after administration (Fig. 3). The

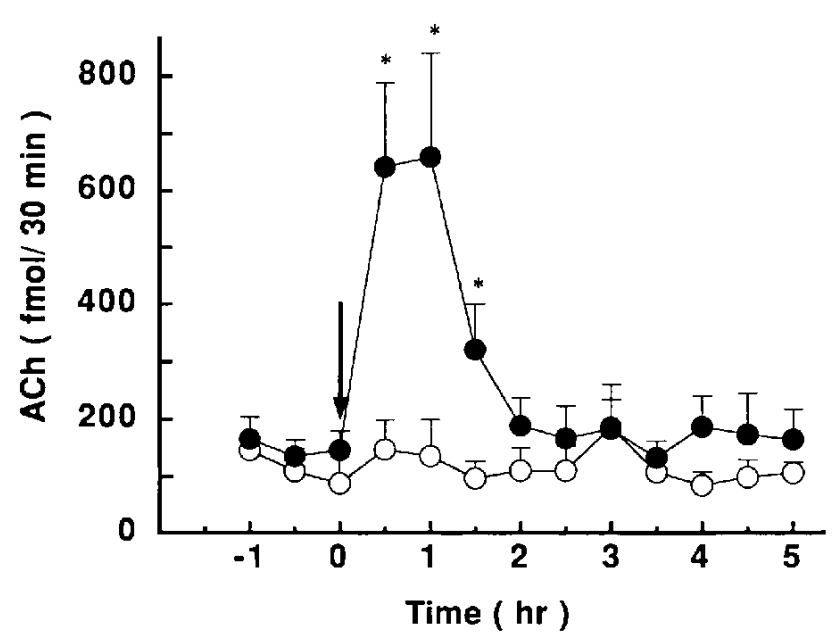

Fig. 3. Effect of PHY on the ACh content in the perfusate from the cerebral cortex of conscious, freely moving rats. Vehicle $(0.9 \%$ saline, $2 \mathrm{ml} / \mathrm{kg}$ ) or PHY was injected i.p. (indicated by arrow). $\bigcirc$, control (vehicle) $(n=6) ; 0,0.5 \mathrm{mg} / \mathrm{kg}(n=7)$. Values are means \pm S.E. ${ }^{*} \mathrm{P}<0.05$ vs control. 


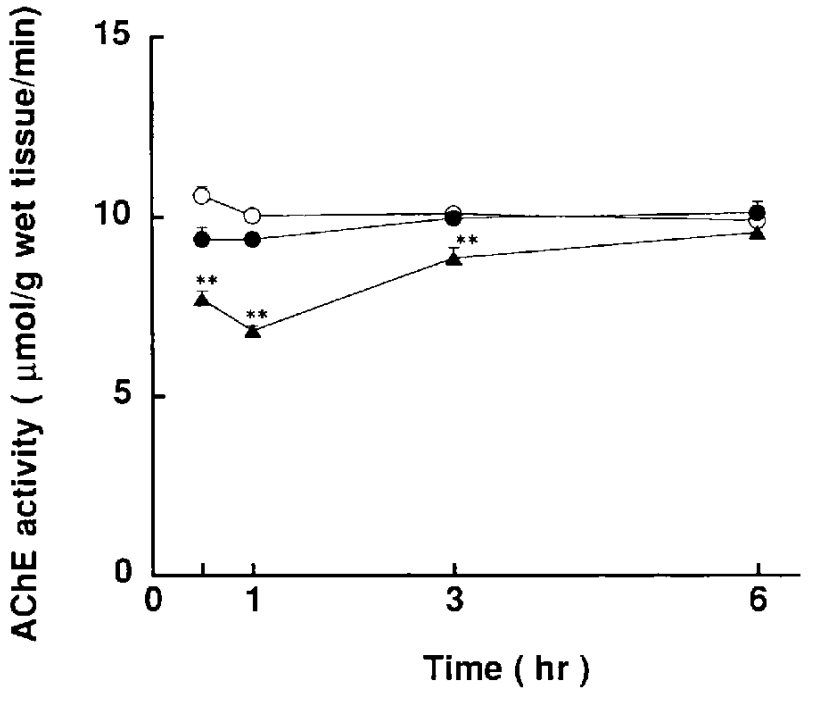

Fig. 4. Effect of NIK-247 on the AChE activity in the cerebral cortex of rats. Vehicle (D.W., $5 \mathrm{ml} / \mathrm{kg}$ ) or NIK-247 was administered orally at $0 \mathrm{hr}$. $\bigcirc$, control (vehicle) $(\mathrm{n}=5-15) ; 0,3.0 \mathrm{mg} / \mathrm{kg}(\mathrm{n}=5-6) ; \boldsymbol{\Lambda}$, $10 \mathrm{mg} / \mathrm{kg}(\mathrm{n}=5-6)$. Values are means \pm S.E. ${ }^{* *} \mathrm{P}<0.01$ vs control.

ACh content in the perfusate returned to the control level $2.0 \mathrm{hr}$ after administration (Fig. 3).

Several mild signs of cholinergic stimulation, such as salivation and tremor, were observed during about the first hour after administration of NIK-247 $(10 \mathrm{mg} / \mathrm{kg}$, p.o.), THA ( $5 \mathrm{mg} / \mathrm{kg}$, p.o.) or PHY ( $0.5 \mathrm{mg} / \mathrm{kg}$, i.p.). The signs induced by NIK-247 and THA was milder than those induced by PHY. These observations were consistent with those reported by Yoshida and Suzuki (10).

\section{Effect of NIK-247 on AChE activity}

We first studied the effect of NIK-247 on AChE activity in the homogenate of rat cerebral cortex. NIK-247 inhibited AChE activity in a dose-dependent fashion, and the $50 \%$ inhibitory concentration $\left(\mathrm{IC}_{50}\right)$ of NIK-247 was found to be $1 \times 10^{-6} \mathrm{M}$. This value of $\mathrm{IC}_{50}$ corresponded well with that reported previously (5).

We then studied the effect of oral administration of NIK-247 on AChE activity in the homogenate of the cerebral cortex. AChE activity in rat cerebral cortex in the control group was $10.04 \pm 0.16 \mu \mathrm{mol} / \mathrm{g}$ wet tissue $/ \mathrm{min}$. NIK-247 administered orally at $10 \mathrm{mg} / \mathrm{kg}$ significantly inhibited AChE activity in rat cerebral cortex (Fig. 4). NIK247 at $10 \mathrm{mg} / \mathrm{kg}$ induced maximal inhibition $(32 \%)$ at 1 $\mathrm{hr}$ after administration, and significant inhibition of AChE activity lasted for $3 \mathrm{hr}$.

\section{DISCUSSION}

Due to limitations in sensitivity for the determination of $\mathrm{ACh}$, most intracerebral microdialysis studies of the effects of drugs on extracellular $\mathrm{ACh}$ concentration have been performed with the addition of a $\mathrm{ChE}$ inhibitor to the perfusion fluid to increase the recovery of $\mathrm{ACh}$ (20, 21). However, the results obtained with such an addition do not necessarily reflect the effects of drugs under basal conditions (12-14). In fact, Messamore et al. (22) reported that the systemic injection of physostigmine or heptylphysostigmine unexpectedly reduced the extracellular concentrations of $\mathrm{ACh}$ when the microdialysis probe was perfused with Ringer's solution containing physostigmine. These findings indicate that determination of the extracellular concentration of $\mathrm{ACh}$ by microdialysis under basal conditions without the addition of $\mathrm{ChE}$ inhibitor to the perfusion fluid is necessary for studying effects of drugs that influence central cholinergic function. In the present study, we therefore measured $\mathrm{ACh}$ content in the perfusate from the cerebral cortex of conscious, freely moving rats without addition of $\mathrm{ChE}$ inhibitor to the perfusion fluid. It is generally accepted that the $\mathrm{ACh}$ content in the perfusate reflects the extracellular concentration directly adjacent to the probe membrane. Accordingly, the increases in ACh content induced by NIK-247, THA and physostigmine observed in this study can be ascribed to increases in extracellular $\mathrm{ACh}$ concentration at the site of dialysis.

Under the experimental conditions we used, basal $\mathrm{ACh}$ in the perfusate was $123.2 \pm 21.8 \mathrm{fmol} / 30 \mathrm{~min}$ and stable throughout the 6.5-hr experimental period (Fig. 1). This value is similar to that for the cerebral cortex reported by $\mathrm{Xu}$ et al. (15).

NIK-247 has previously been reported to increase basal and $\mathrm{K}^{+}$-stimulated $\mathrm{ACh}$ efflux from rat brain slices (11). In the present study, oral administration of NIK-247 and THA increased the extracellular concentration of ACh in the cerebral cortex of conscious, freely moving rats (Figs. 1 and 2). The degree of increase induced by NIK-247 at $10 \mathrm{mg} / \mathrm{kg}$ was almost equal to that induced by THA at 5 $\mathrm{mg} / \mathrm{kg}$. These results are consistent with the finding that the AChE inhibitory activity of NIK-247 in vitro is about one-third that of THA (5). The increase in extracellular concentration of ACh induced by PHY was rapid compared with that by NIK-247 and THA, probably because PHY was injected i.p. The effect of PHY peaked at 0.5-1 hr and disappeared within $2 \mathrm{hr}$ after administration. These findings are consistent with those of Messamore et al. (17).

Oral administration of NIK-247 at $10 \mathrm{mg} / \mathrm{kg}$ significantly inhibited AChE activity in the cerebral cortex. Maximal inhibition was observed at $1 \mathrm{hr}$ and significant inhibition persisted for at least $3 \mathrm{hr}$ after administration. The effect of NIK-247 on extracellular ACh concentration was consistent to a certain extent with that on AChE-activity. However, the duration of the increase in extracellular 
ACh concentration induced by NIK-247 was shorter than its AChE-inhibitory effect. Similarly, Messamore et al. (17) reported some discrepancies between $\mathrm{ACh}$ content in the perfusate and $\mathrm{AChE}$ inhibition determined ex vivo following systemic injection of ChE inhibitors. These findings indicate that extracellular $\mathrm{ACh}$ concentration determined under basal conditions by microdialysis is a more reliable index of functional activity than $\mathrm{AChE}$ activity for determination of the effects of drugs on central cholinergic transmission.

4-Aminopyridine (4-AP), a $\mathrm{K}^{+}$channel inhibitor, has been reported to increase the release of $\mathrm{ACh}$ from cholinergic nerve endings (23). In addition to AChE inhibition, NIK-247 and THA have $\mathrm{K}^{+}$channel inhibitory activity, and their $\mathrm{IC}_{50}$ values are $1 \times 10^{-3} \mathrm{M}$ and $5 \times 10^{-4}$ $M$, respectively $(24,25)$. These findings suggest that AChE inhibition can not be used to accurately predict extracellular ACh concentration after systemic administration of NIK-247 and THA.

In conclusion, the findings of this study demonstrate that oral administration of NIK-247 inhibits AChE activity and increases extracellular ACh concentration in the cerebral cortex of conscious, freely moving rats, and they suggest that NIK-247 facilitates central cholinergic transmission. NIK-247 is thus a promising candidate for use in palliative therapy of Alzheimer's disease.

\section{REFERENCES}

1 Bowen DW, Smith CB, White $P$ and Davision AN: Neurotransmitter-related enzymes and indices of hypoxia in senile dementia and other abiotrophies. Brain 99, 459-496 (1976)

2 Whitehouse PJ, Price DR, Struble RG, Clark AW, Coyle JT and Delong MR: Alzheimer's disease and senile dementia: Loss of neurons in the basal forebrain. Science 215, 1237-1239 (1982)

3 Davies $P$ and Maloney AJF: Selective loss of central cholinergic neurons in Alzheimer's disease. Lancet 2, 1403 (1976)

4 Henke $\mathrm{H}$ and Lang W: Cholinergic enzymes in neocortex, hippocampus and basal forebrain of non-neurological and senile dementia of Alzheimer-type patients. Brain Res 267, 281-291 (1983)

5 Shibanoki S, Ishii $Y$, Kubo T, Kogure M, Asai S and Ishikawa K: Effect of 9-amino-2,3,5,6,7,8-hexahydro- $1 H$-cyclopenta-(b)quinoline monohydrate hydrochloride (NIK-247) on cholinergic enzyme activity in rats. Pharmacol Biochem Behav 39, 499-502 (1991)

6 Nabeshima T, Yoshida S and Kameyama T: Effects of the novel compound NIK-247 on impairment of passive avoidance response in mice. Eur J Pharmacol 154, 263-270 (1988)

7 Kuribara $\mathbf{H}$ : Effects of amiridin on ambulatory activity and discrete shuttle avoidance response in mice. Folia Pharmacol Jpn 88, 299-307 (1986) (Abstr in English)

8 Ueki A and Miyoshi K: Effects of cholinergic drugs on learning impairment in ventral globus-lesioned rats. J Neurol Sci 90, $1-21$ (1989)
9 Yamamoto T, Ohno M, Kitajima I, Yatsugi S and Ueki S: Ameliorative effects of working memory in rats. Physiol Behav $53,5-10(1993)$

10 Yoshida S and Suzuki N: Antiamnesic and cholinomimetic sideeffects of the cholinesterase inhibitors, physostigmine, tacrine and NIK-247 in rats. Eur J Pharmacol 250, 117-124 (1993)

11 Ishii $Y$ and Sumi T: Evaluation of a cholinergic drug, 9-amino2,3,5,6,7,8-hexahydro-1 $H$-cyclopenta-(b)-quinoline (NIK-247), as an enhancer of endogenous efflux of acetylcholine from brain slices. Neuropharmacology 31, 61-66 (1991)

12 Kawashima K, Hayakawa T, Kashima Y, Suzuki T, Fujimoto K and Oohata $\mathrm{H}$ : Determination of acetylcholine release in the striatum of anesthetized rats using in vivo microdialysis and a radioimmunoassay. J Neurochem 57, 882-887 (1991)

13 De Bore P, Westerink BHC and Horn AS: The effects of acetylcholine from the striatum in vivo: interaction with autoreceptor responses. Neurosci Lett 116, 357-360 (1990)

14 Damsma G, Westerink BHC, De Bore P, De Vries JB and Horn AS: Basal acetylcholine release in freely moving rats detected by on-line trans-striatal dialysis: Pharmacological aspects. Life Sci 43, $1161-1168$ (1988)

15 Xu M, Nakamura Y, Yamamoto T, Natori K, Irie T, Utsumi H and Kato $T$ : Determination of basal acetylcholine release in vivo by rat brain dialysis with a U-shaped cannula. Neurosci Lett 123, $179-182$ (1991)

16 Kosasa T, Yamanishi Y, Ogura H and Yamatsu K: Effects of E2020 on the extracellular level of acetylcholine in the rat cerebral cortex measured by microdialysis without addition of cholinesterase inhibitor. Eur J Pharmacol 183, 1936 (1990)

17 Messamore E, Warpman U, Ogano $N$ and Giacobini E: Cholinesterase inhibitor effects on extracellular acetylcholine in rat cortex. Neuropharmacology 32, 745-750 (1993)

18 Paxinos G and Watson C: The Rat Brain in Stereotaxic Coordinates. Academic Press, New York (1982)

19 Zusho H: The method for determination of the initial state of cholinesterase (ChE) activity by $\mathrm{pH}$-electrode. Folia Pharmacol Jpn 68, 495-503 (1972) (Abstr in English)

20 Consolo $\mathrm{S}, \mathrm{Wu}$ CF, Fiorentini F, Ladinsky $\mathrm{H}$ and Vezzani A: Determination of endogenous acetylcholine release in freely moving rats by transstriatal dialysis coupled to a radio-enzymatic assay: Effect of drugs. J Neurochem 48, $1459-1465$ (1987)

21 Damsma G, Westerink BHC, De Vries JB, Van den Berg CJ and Horn AS: Measurement of acetylcholine release in freely moving rats by means of automated intracerebral dialysis. J Neurochem 48, 1523-1528 (1987)

22 Messamore E, Ogane $\mathrm{N}$ and Giacobini E: Cholinesterase inhibitor effects on extracellular acetylcholine in rat striatum. Neuropharmacology 32, 291-296 (1993)

23 Buyukuysal RL and Wurtman RJ: Tetrahydroaminoacridine but not 4-aminopyridine inhibits high-affinity choline uptake in striatal and hippocampal synaptosomes. Brain Res $\mathbf{4 8 2}$, $371-375$ (1989)

24 Kojima J, Sugawara Y and Obara A: NIK-247 blocks voltagedependent ionic currents in crayfish axon. Jpn J Pharmacol 57, 545-552 (1991)

25 Drukarch B, Kits KS, Van der Meer EG, Lodder JC and Stoof JC: 9-Amino-1,2,3,4-tetrahydroacridine (THA), an alleged drug for the treatment of Alzheimer's disease, inhibits acetylcholinesterase activity and slow outward $\mathbf{K}^{+}$current. Eur J Pharmacol 141, 153-157 (1987) 